Scientia Marina 77(1)

March 2013, 81-93, Barcelona (Spain)

ISSN: 0214-8358

doi: $10.3989 /$ scimar.03691.04A

\title{
An analysis of fishing gear competition. Catalan fisheries as case studies
}

\author{
JORDI LLEONART, FRANCESC MAYNOU and JORDI SALAT \\ Institut de Ciències del Mar, CSIC, Pg. Marítim de la Barceloneta 37-49, E-08003 Barcelona, Spain. \\ E-mail: 1leonart@icm.csic.es
}

\begin{abstract}
SUMMARY: An asymmetric index was developed to measure the competition relationships among fishing fleets (or gears or métiers) in a multispecies fishery. This index can be used to measure the degree of dominance of each fleet and its level of independence from competition. To illustrate the concepts, the index is applied to two case studies using two datasets, both from Catalonia, NW Mediterranean. The results show that in both case studies the dominance of bottom trawl over most other gears (especially small-scale ones) is evidenced and quantitatively measured. Bottom trawl is also highly independent of the others. Purse seine appears to be quite independent, but not dominant over the other gears. A practical use of these asymmetric indices is to assist fisheries managers in the decision-making process to optimize the allocation of fishing effort, including energy efficiency, and to reduce environmental impact.
\end{abstract}

Keywords: gear competition, asymmetric index, Mediterranean fisheries.

RESUMEN: ANÁlisis DE LA COMPETENCIA ENTRE ARTES DE PESCA. LAS PESQUERÍAs CATALANAS COMO EJEMPLO. - Se desarrolló un índice asimétrico para medir las relaciones de competencia entre flotas pesqueras (o artes de pesca o métiers) en el caso de pesquerías multiespecíficas. Este índice permite medir el dominio de una flota sobre otra u otras, y su nivel de independencia. Estos conceptos se ilustran con dos conjuntos de datos de Cataluña, Mediterráneo noroccidental. En estos ejemplos se pone de manifiesto el dominio de arrastre de fondo sobre la mayoría de los otros artes (en especial sobre la pesca artesanal) y se mide cuantitativamente. El arrastre de fondo es también altamente independiente de los demás. El cerco de pequeños pelágicos parece ser muy independiente, pero no dominante en los otros artes. Un uso práctico de estos índices asimétricos es ayudar a los gestores de la pesca en el proceso de toma de decisiones para optimizar la asignación del esfuerzo pesquero.

Palabras clave: competencia entre flotas, índice asimétrico, pesquerías Mediterráneas.

\section{INTRODUCTION}

Most Mediterranean fisheries are characterized by the activity of several different gears working on a multispecies environment (métiers, Pelletier and Ferraris 2000). Each gear exerts a different selectivity pattern on each species, so different métiers may affect a fish population in different stages of its life history. This pattern may be due to the technical aspects (i.e. mesh or hook size) of specific gear, and also to the environment (depth, habitat) where a particular gear is deployed or the skipper's knowledge or local tradition (Maynou et al. 2011).
The management of multispecies, multigear fisheries is a problem typical of mixed fisheries. This problem has often been approached from the perspective of technological interactions in the capture of particularly important species (e.g. Aldebert et al. 1993 and Aldebert and Recasens 1996 for hake; Demestre et al. 1997 for red mullet; Stergiou et al. 1996 and Erzini et al. 2003 for multispecies fishery). These studies show, for instance, that trawling with low selectivity and high catches of juvenile European hake (Merluccius merluccius) negatively affects the profitability of set gear fleets (longliners and gillnetters) (Lleonart et al. 2003, Merino et al. 2007). The technical interactions between 
fishing gears is also important in the study of fisheriesinduced evolution (Kuparinen et al. 2009).

Here we propose a multivariate approach based on an asymmetric index to identify and quantify the relationships of dominance and competition among fishing fleets or métiers sharing resources in a mixed fishery.

Competition is an asymmetric relationship because competitors are unequal. There are generalist (or opportunistic) vs specialized fleets and gears; large fleets and small ones; highly mobile and less mobile fleets; and gears targeting large fish and gears targeting small fish. In ecology, different types of asymmetric indices have been developed either to assess the predator-prey relationships in trophic webs (Gallopín 1972) or to measure niche overlap among species (Mouillot et al. 2005, Pledger and Geange 2009). These indices are usually appropriate to field collected data in which the relative abundance of species in their environment is usually related to preference of trophic resources or gradients of environmental variables. Their applicability to fisheries landing data is limited because these data do not inform about the environment in which a fish was caught and the species fished are a collection of items selected based on their commercial importance, regardless of their ecological role.

The objective of this paper is to introduce an asymmetric index that is easily applicable to fisheries landing data and can be used to quantify the competition relationships among fleets or métiers for common fish resources. This index introduces the concept of dominance of one fleet over another, meaning the impact of the first fleet on the common resources of the two fleets. It can also be used to calculate overall dominance and dependence indices (a measure of shared resources) for each fleet.

The approach is illustrated with two case studies from data of Catalan fisheries for the 10-year period 2000-2009.

\section{MATERIALS AND METHODS}

\section{Data source}

Two different data sets were used, one for each case study. The first one was the official statistics of Catalonia from 2000 to 2009 (the daily fish sales database of the General Fisheries Directorate of the Catalan Government, not published). The data come from the daily auctions by boat and species. Boats are classified according to fishing gear into five classes, following the official types of license issued by the local Fisheries Department: bottom trawl, purse seine, bottom longline, surface longline and small-scale vessels. These five types correspond to otter bottom trawl, purse seine, set longline, drifting longline and passive gear for vessels 0-12 $\mathrm{m}$ length, according to the classification used in the EU Data Collection Framework (Commission Regulation (EC) No. 665/2008). The total number of species (or species groups) reported in the statistics is 198, although 37 make up $90 \%$ of the catch. As shown in Appendix
1, the trawl fleet and the purse seine fleet produce the highest catches, although the former is more diverse and depends on a higher amount of species than the latter.

Taxa such as Osteichthyes and Invertebrata could be included or excluded from the analysis, although it is not clear whether this inclusion or exclusion would be advantageous. This uncertainty reflects the inaccuracy of species identification of commercial landing reports. In this paper these species groups have been included in the analysis. In the data set there are 26 groups in the 198 taxa. Of these groups, 10 are genera without species definition (such as Lophius sp. or Mullus sp.), 7 are families (such as Gobiidae or Labridae) and 9 represent higher taxonomic groups (such as Crustacea or Chondrichthyes). Since there is no objective criterion for including or excluding species groups, we chose to follow the FAO reporting standards and include them.

The second case study refers to a single harbour, Vilanova i la Geltrú, during the same period (2000-2009), for which data were taken from the daily fish sales database of the General Fisheries Directorate of the Catalan Government (not published). The raw data also include the daily catch by boat and species, but in this case the vessels were divided into 11 métiers according to the multivariate analysis published by Maynou et al. (2011). The number of species, or taxonomic units, reported was 132. The two main fishing types, in terms of catches, are bottom trawl and purse seine, as in the previous case, but nine other small-scale métiers were revealed in the multivariate analysis: trammel nets targeting cuttlefish (a métier known as "cuttlefish"), gillnets targeting European hake ("g-hake"), bottom longlines targeting European hake ("l-hake"), clay pots targeting octopus ("octopus"), trammel nets targeting striped red mullet ("redmullet"), trammel nets targeting sole ("sole") and trammel nets targeting striped seabream and other sparids ("varied"), towed dredges targeting coastal bivalves ("dredge") and toothed beam trawl targeting sea snails ("beam trawl") (Appendix 2).

The data used in this second case study show some apparent inconsistencies, such as the fact that the octopus clay pot fishery accounts for only $78 \%$ of octopus. This is not because of data errors but rather inaccuracies in the commercial reports, which have a minimum resolution of one day. Small-scale fishers often use different gears (i.e. pots and small longlines) in the same day and they report the whole catch for only one gear. These inaccuracies have been respected in order to keep the approach realistic with real inaccurate data.

The reason for using these two data sets is to analyse different scales. The first case study covers a wide geographical range with few great gear groups, while the second one is much finer in grouping gears (actually métiers) although it only refers to a single harbour.

Although the original data were collected at a daily temporal scale, they have been aggregated at an annual scale to illustrate the application of the metrics described herein. Figure 1 shows the study area and the annual catches of the fleets studied. 


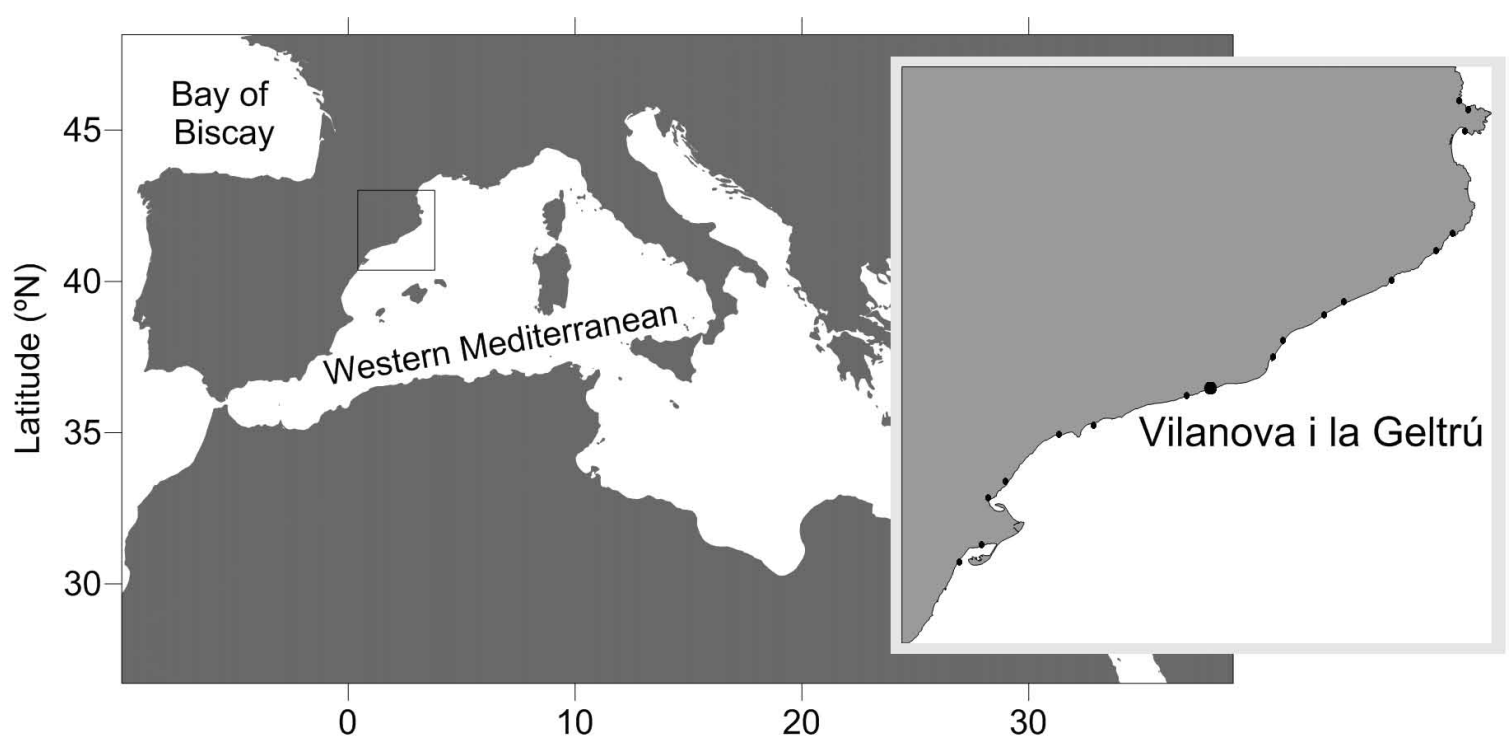

Longitude $\left({ }^{\circ} \mathrm{E}\right)$
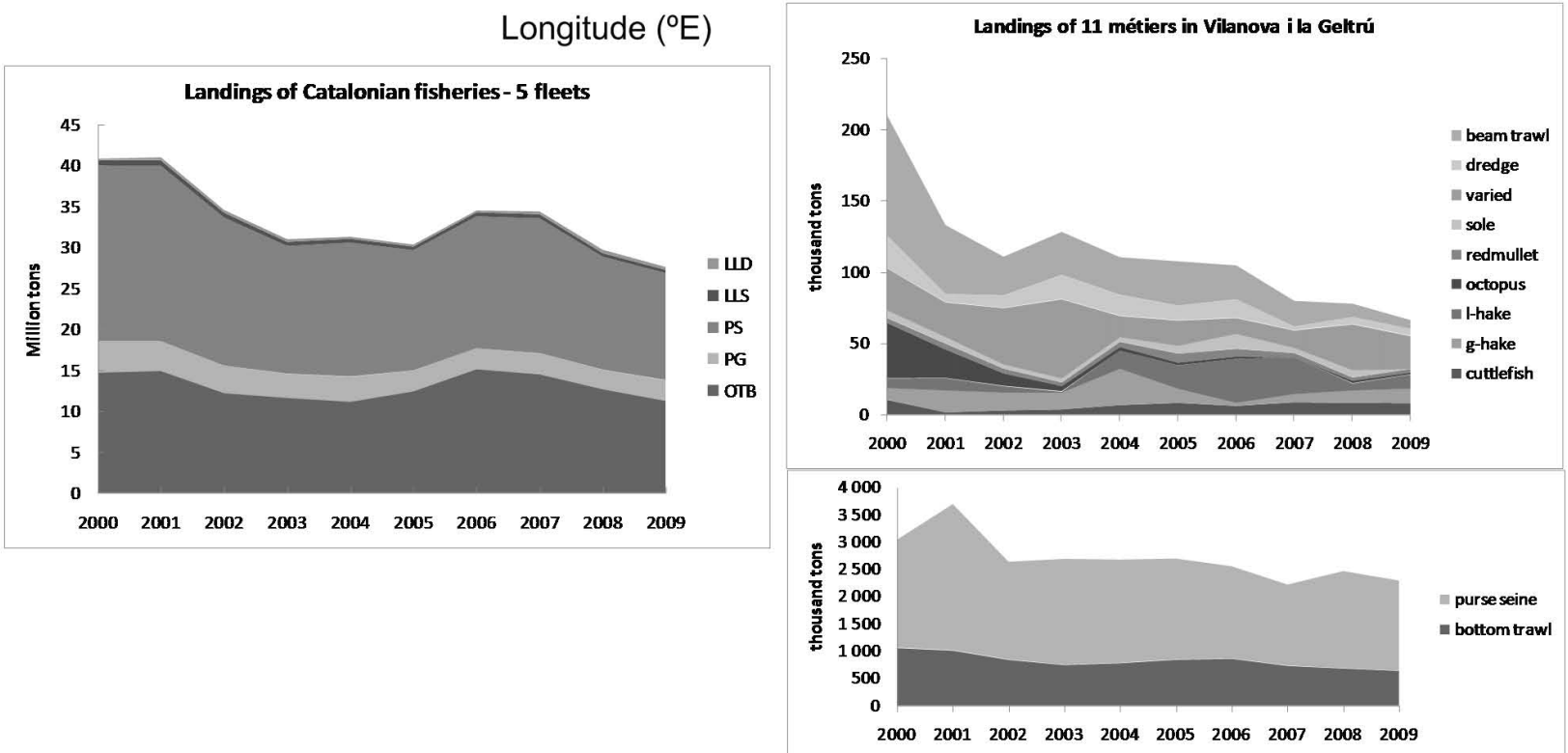

FIG. 1. - Location of the study area. The lower panels show: left, the evolution of catches of the five fishing fleets operating in Catalonia according to the official typologies of license: OTB (otter bottom trawl), PS (purse seine), LLS (set longline), LLD (drifting longline) and PG (passive gear for vessels of $0-12 \mathrm{~m}$ length); right, the evolution of the catches of the 11 métiers practiced in the Vilanova i la Geltrú fishery.

\section{A metrics for measuring the competition among fleets or métiers}

We are dealing with a multispecies fishery in which a number of vessels using several gears are acting. Let us consider a "fleet" to be a group of vessels practising the same métier.

Let $n$ be the total number of species (or taxa) and $m$ the total number of fleets working on the fishery. Let [D] be an $n \times m$ matrix where each element $d_{i j}$ is the total weight of species $i$ caught by fleet $j$ during a period of time (e.g. one year).

Two new matrices [P] and [Q], both $n \times m$, can be obtained from [D] according to the following definitions of their elements:

$$
p_{i j}=\frac{d_{i j}}{\sum_{j}^{m} d_{i j}} \text { and } q_{i j}=\frac{d_{i j}}{\sum_{i}^{n} d_{i j}}
$$

$p_{i j}$ is the relative weight that fleet $j$ represents for species $i$. The effect of species abundance is eliminated.

$q_{i j}$ represents the relative weight of the species $i$ in the catch of fleet $j$. The effect of fleet size is therefore eliminated.

Given two fleets, $A$ and $B$, the following index can be defined:

$$
r_{i A B}=p_{i A} \cdot q_{i B}
$$


The meaning of $r_{i A B}$ is as follows: $p_{i A}$ is the proportion of the total catch of species $i$ caught by fleet $A$. If fleet $A$ captures most of species $i$ it deprives other fleets of this resource, so $p_{i A}$ represents the importance of $A$ in the capture of $i . q_{i B}$ is the proportion of species $i$ in the total catch of fleet $\mathrm{B}$. The higher the value of $q_{i B}$, the more important this species is for fleet $B$. If $p_{i A}$ and $q_{i B}$ are both high, this means that $A$ captures most of $i$, which is an important resource for $B$, so $A$ is a strong competitor against $B$ regarding species $i$. If $p_{i A}$ is low and $q_{i B}$ is high, the species $i$ is important for $B$, and $A$ is not a heavy competitor for this resource. If $p_{i A}$ is high and $q_{i B}$ is low, $A$ captures a good deal of $i$, but this species is not very important for $B$. Finally, if both $p_{i A}$ and $q_{i B}$ are low, the species $i$ is not important either for $A$ or $B$, and is probably the target of other fleets.

This index measures the competition of $A$ with $B$ concerning only species $i$. This index is asymmetric because the competition of $A$ with $B$ is different than that of $B$ with $A\left(r_{i A B} \neq r_{i B A}\right)$. is then

The interaction of $A$ with $B$ considering all species

$$
s_{A B}=\sum_{i}^{n} r_{i A B}
$$

where $s_{A B}$ is the index expressing the competition of fleet $A$ with fleet $B$. It ranges between 0 and 1 . For instance, if a gear $A$ is getting high catches on most of the target species of gear $B, s_{A B}$ will be close to 1 , so $A$ must be considered as a strong competitor of, or dominant over, $B$. If the set of species targeted by $A$ were different from the set caught by $B, s_{A B}$ would be close to 0 , so $A$ would be an irrelevant competitor of $B$. As expected, the index $s_{A B}$ is asymmetric $\left(s_{A B} \neq s_{B A}\right)$, as are the competition relationships.

$s_{A B}$ is an element of a new $m \times m$ matrix called [S]. This matrix is computed as

$$
\mathbf{S}=\mathbf{P}^{\mathrm{T}} \cdot \mathbf{Q}
$$

Therefore, $[\mathbf{S}]$ is the matrix of interactions, or competition, between fleets.

The main diagonal of [S], or competition of a fleet with itself, can be interpreted as the level of independence of the corresponding fleet. If a fleet captures only species not caught by any other fleet, its value is 1 (the only competitor of a fleet is itself) and there is no interaction with others. If the species composition of a fleet is the same as that of another fleet or fleets but its catch is much lower, that value approaches 0 and the catch composition of this fleet is highly dependent on others.

An overall measure of the dominance of a fleet $(A)$ over all the other fleets (minus itself) could be calculated as

$$
T_{A}=\sum_{j}^{m} s_{A j}-s_{A A}
$$

Asymmetric indices are not as easy to represent as symmetric ones, which can be managed through a series of multivariate statistical tools, mainly cluster analysis and diagonalization methods such as principal component analysis and similar procedures, which allow meaningless dimensions to be removed and cluster structures to be synthesized. As far as we know, there is no statistical tool for representing asymmetric relationships; only "sociograms", a type of non-quantitative graphs showing the asymmetric relationships between "individuals" used in social sciences, appear to be commonly used in such studies.

A sociogram consists in representing the elements (fleets) as circles. The diameter could represent any feature of the fleet. In the present case we use two concentric circles: the independence and the overall dominance. The circles are connected by asymmetric arrows with the width of the ends proportional to $\mathrm{s}_{\mathrm{AB}}$, near to fleet $\mathrm{A}$, and $\mathrm{s}_{\mathrm{BA}}$, near to fleet $\mathrm{B}$. When the pairs $\mathrm{s}_{\mathrm{AB}}, \mathrm{s}_{\mathrm{BA}}$ are both smaller than a given value (i.e. 0.05), they are not represented to improve readability. This simplification was applied only to the case of 11 fleets, involving 55 pair relationships. The software used for sociogram representation can be found in Lewejohann (2005).

\section{RESULTS}

\section{Catalonia five-fleet data set}

Catches with purse seine and bottom trawl were far greater than those with the other three gears (Fig. 1) throughout the time series.

The structure of matrix $[\mathbf{S}]$ was very similar across years. Linear correlation between pairs of years was 0.98 or higher, so $[\mathbf{S}]$ mean is shown, as an example, in Table 1.

This table also shows the standard deviation matrix of the ten annual $[\mathbf{S}]$ matrices. The standard deviation of the matrix elements across years confirms the relative temporal stability, with a possible single exception

TABLE 1. - Five-fleet results for Catalonia. 2000-2009 average [S] and standard deviation matrices. For each element $\mathrm{S}_{\mathrm{AB}}$, A correspond to the rows and $B$ to the columns (for instance $S_{O T B, P G}=0.40$ ). The main diagonal of the matrix corresponds to the level of "independence" of each fleet. $T$ is the measure of dominance. OTB, otter bottom trawl; PG, passive gear; PS; purse seine; LLS, stet longline; LLD, drifting longline.

\begin{tabular}{lcccccc}
\hline & OTB & PG & PS & LLS & LLD & T \\
\hline Average [S] & & & & & & \\
OTB & 0.80 & 0.40 & 0.07 & 0.53 & 0.14 & 1.14 \\
PG & 0.09 & 0.43 & 0.02 & 0.25 & 0.19 & 0.55 \\
PS & 0.09 & 0.10 & 0.91 & 0.08 & 0.04 & 0.31 \\
LLS & 0.02 & 0.04 & 0.00 & 0.10 & 0.09 & 0.15 \\
LLD & 0.00 & 0.02 & 0.00 & 0.05 & 0.54 & 0.07 \\
\multicolumn{1}{l}{ Standard deviation } & & & & & \\
OTB & 0.02 & 0.03 & 0.02 & 0.06 & 0.07 & \\
PG & 0.01 & 0.03 & 0.00 & 0.03 & 0.09 & \\
PS & 0.02 & 0.03 & 0.01 & 0.04 & 0.04 & \\
LLS & 0.00 & 0.01 & 0.00 & 0.02 & 0.03 & \\
LLD & 0.00 & 0.01 & 0.00 & 0.02 & 0.16 & \\
\hline
\end{tabular}




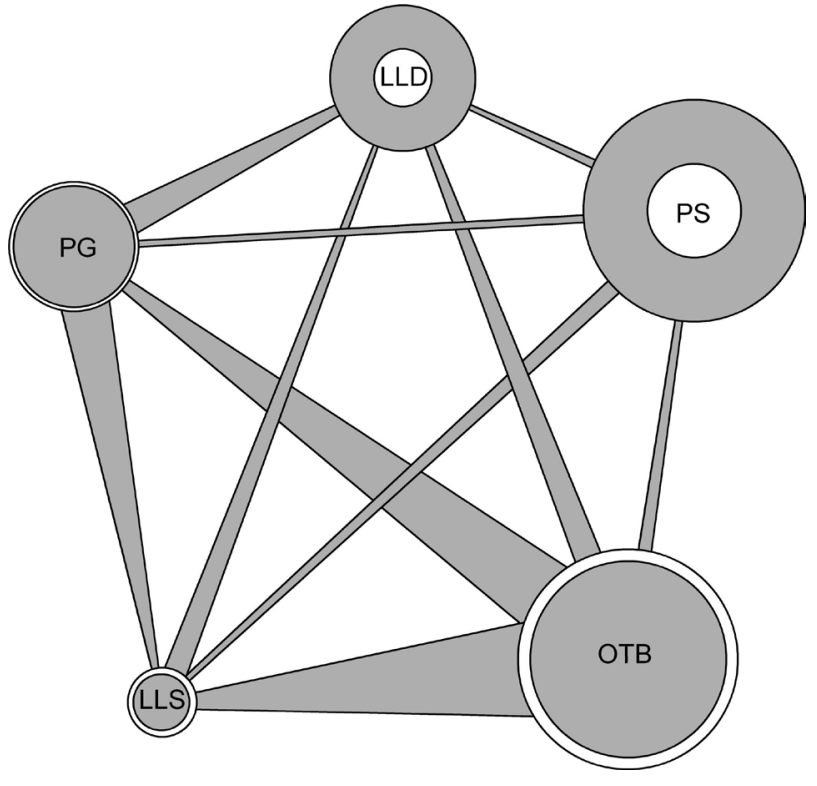

FIG. 2. - Sociogram of five fleets in Catalonia. The white circle is proportional to $\mathrm{T}$ (dominance) the grey one to the main diagonal (independence).

in the main diagonal element for surface longline. A sociogram of the average $[\mathbf{S}]$ is presented in Figure 2.

It must be noted that the first three higher values are found in the main diagonal, and correspond to purse seine, trawl and drifting longline, which means that they were the least dependent fleets in terms of species composition, though drifting longline was really very small in terms of catches. Bottom trawl is a strong competitor of the bottom longline (0.53) and

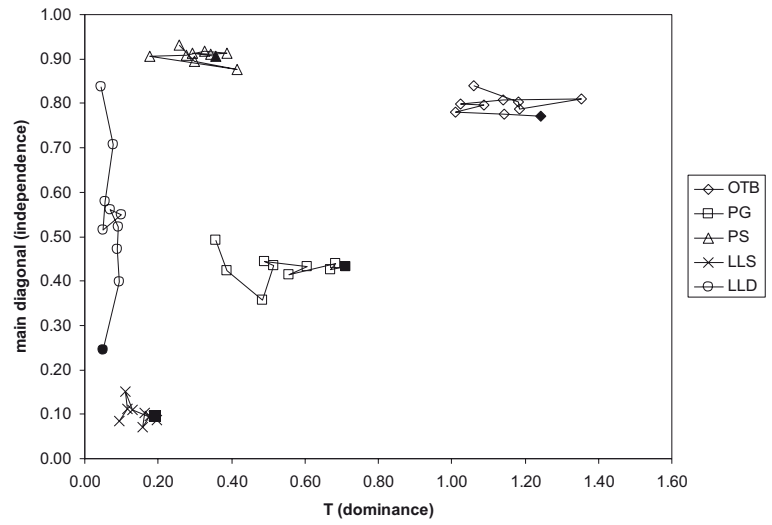

FIG. 3. - Independence vs dominance plot of five fleets in Catalonia, showing the annual trends. The first year of the series (2000) is indicated by a solid dot.

small-scale fleets (0.40). The rest of the interactions were quite small, although some dominance of the small-scale fleet over longlines and of bottom trawl over drifting longline were observed.

The analysis of the trends of the main diagonal, as an indicator of independence (or self-dependence) among fleets (Fig. 3), shows that purse seine is the most independent fleet. This is because its target species, mainly sardine and anchovy, are not significantly targeted by any other fleet. Bottom trawl is also quite independent, while passive gear and bottom longline fleets have a fairly low independence level. This means that their catch composition is shared with other fleets, but bottom trawl takes a higher share. Among those

TABLE 2. - Eleven-fleet results for Vilanova i la Geltrú. 2000-2009 average [S] and standard deviation matrices. For each element $\mathrm{S}_{\mathrm{AB}}$, A correspond to the rows and B to the columns (for instance $S_{\text {bottom trawl, cuttlefish }}=0.43$ ). The main diagonal of the matrix corresponds to the level of "independence" of each fleet. $T$ is the measure of dominance.

\begin{tabular}{|c|c|c|c|c|c|c|c|c|c|c|c|c|}
\hline & cuttlefish & g-hake & 1-hake & octopus & redmullet & sole & varied & dredge & $\begin{array}{l}\text { beam } \\
\text { trawl }\end{array}$ & $\begin{array}{c}\text { bottom } \\
\text { trawl }\end{array}$ & $\begin{array}{l}\text { purse } \\
\text { seine }\end{array}$ & $\mathrm{T}$ \\
\hline \multicolumn{13}{|l|}{ Average } \\
\hline g-hake & 0.01 & 0.04 & 0.04 & 0.01 & 0.01 & 0.02 & 0.02 & 0.00 & 0.01 & 0.01 & 0.00 & $\begin{array}{l}0.23 \\
0.12\end{array}$ \\
\hline l-hake & 0.00 & 0.04 & 0.08 & 0.00 & 0.00 & 0.01 & 0.01 & 0.00 & 0.00 & 0.01 & 0.00 & 0.08 \\
\hline octopus & 0.03 & 0.00 & 0.00 & 0.07 & 0.01 & 0.04 & 0.01 & 0.01 & 0.01 & 0.01 & 0.00 & 0.11 \\
\hline redmullet & 0.01 & 0.01 & 0.00 & 0.01 & 0.14 & 0.01 & 0.01 & 0.00 & 0.00 & 0.00 & 0.00 & 0.07 \\
\hline sole & 0.07 & 0.01 & 0.00 & 0.04 & 0.01 & 0.21 & 0.02 & 0.00 & 0.03 & 0.00 & 0.00 & 0.19 \\
\hline varied & 0.07 & 0.05 & 0.01 & 0.05 & 0.08 & 0.09 & 0.16 & 0.02 & 0.02 & 0.01 & 0.00 & 0.41 \\
\hline dredge & 0.02 & 0.00 & 0.00 & 0.01 & 0.01 & 0.01 & 0.01 & 0.78 & 0.01 & 0.00 & 0.00 & 0.07 \\
\hline beam trawl & 0.16 & 0.01 & 0.00 & 0.06 & 0.02 & 0.15 & 0.02 & 0.01 & 0.66 & 0.01 & 0.00 & 0.45 \\
\hline bottom trawl & 0.43 & 0.68 & 0.83 & 0.64 & 0.57 & 0.28 & 0.39 & 0.14 & 0.22 & 0.83 & 0.05 & 4.23 \\
\hline purse seine & 0.10 & 0.15 & 0.03 & 0.07 & 0.11 & 0.08 & 0.32 & 0.03 & 0.00 & 0.11 & 0.94 & 1.02 \\
\hline \multicolumn{13}{|c|}{ Standard deviation } \\
\hline cuttlefish & 0.10 & 0.01 & 0.00 & 0.03 & 0.02 & 0.06 & 0.02 & 0.01 & 0.03 & 0.00 & 0.00 & \\
\hline g-hake & 0.01 & 0.01 & 0.02 & 0.01 & 0.01 & 0.02 & 0.01 & 0.00 & 0.00 & 0.00 & 0.00 & \\
\hline l-hake & 0.01 & 0.03 & 0.07 & 0.00 & 0.00 & 0.01 & 0.01 & 0.00 & 0.00 & 0.01 & 0.00 & \\
\hline octopus & 0.03 & 0.00 & 0.00 & 0.08 & 0.01 & 0.03 & 0.01 & 0.01 & 0.01 & 0.01 & 0.00 & \\
\hline redmullet & 0.00 & 0.01 & 0.00 & 0.01 & 0.06 & 0.01 & 0.01 & 0.00 & 0.00 & 0.00 & 0.00 & \\
\hline sole & 0.03 & 0.01 & 0.00 & 0.03 & 0.01 & 0.07 & 0.02 & 0.00 & 0.02 & 0.00 & 0.00 & \\
\hline varied & 0.03 & 0.03 & 0.01 & 0.04 & 0.04 & 0.04 & 0.11 & 0.02 & 0.02 & 0.01 & 0.00 & \\
\hline dredge & 0.01 & 0.00 & 0.00 & 0.01 & 0.00 & 0.01 & 0.01 & 0.11 & 0.00 & 0.00 & 0.00 & \\
\hline beam trawl & 0.09 & 0.01 & 0.00 & 0.03 & 0.01 & 0.04 & 0.01 & 0.01 & 0.15 & 0.00 & 0.00 & \\
\hline bottom trawl & 0.08 & 0.05 & 0.07 & 0.09 & 0.07 & 0.05 & 0.12 & 0.07 & 0.09 & 0.03 & 0.01 & \\
\hline purse seine & 0.07 & 0.07 & 0.01 & 0.05 & 0.05 & 0.06 & 0.12 & 0.02 & 0.00 & 0.04 & 0.01 & \\
\hline
\end{tabular}


fleets, it is interesting to observe that drifting longline displays a temporal trend of increasing independence (from approximately 0.25 to 0.85 in Fig. 3), possibly related to its progressive specialization. In terms of dominance, bottom trawl appears to be the most dominant, thus being the most competitive (highly independent and dominant) of the fleets, followed by the small-scale fleet. Set longline is the most affected by competition because it is highly dependent and less dominant (Fig. 3).

\section{Vilanova i la Geltrú, 11 métier data set}

As in the previous case study, the correlation between matrices $[\mathbf{S}]$ of successive years is higher than 0.95 . Table 2 shows the average and standard deviation of the elements of the annual [S]. The sociogram of [S] is presented in Figure 4.

Regarding independence, four fleets show values above 0.5: bottom trawl, purse seine, beam trawl and dredge. The other seven are quite dependent, below 0.4. Bottom trawl is by far the most dominant fleet with $\mathrm{T}$ values around 4 , purse seine has $\mathrm{T}$ values around 2 and all the other fleets have $\mathrm{T}$ values below 1 (Fig. 5). Dredge shows a trend to become more independent although it is not dominant because it is very specialized, targeting only bivalves. Beam trawl shows the opposite trend towards increasing its dependency on competitors. The remaining seven gears are both dominated and dependent and do not show significant trends over time.

\section{DISCUSSION}

The analyses carried out have quantified a set of relationships that are more or less qualitatively known by fisheries experts. However, it is also known that the lack of quantification could mislead the interpretation of relationships because of prejudices or preconceptions. The asymmetric index presented here helps the analyst to better understand the quantitative relationships between fishing gears or métiers in competitive multispecies fisheries. For instance, in the fisheries analysed here (as elsewhere in the Mediterranean) bottom trawl fleets are clearly dominant, in the sense that they produce large catches of species which are shared with other fleets, and they are independent of smallscale fleets that cannot compete in terms of landings. On the other hand, the Mediterranean purse seine fleet has low dominance and high independence because of its specialized target resource (small pelagics). In general, small-scale fisheries in the Mediterranean show an asymmetric relationship with bottom trawl and their long-term viability can be ensured only if they become more specialized (e.g. more independent, like surface longline in Catalonia and dredges in Vilanova i la Geltrú) or if market differentiation of the fish product can be enhanced (e.g. added value of high-quality large fish from small-scale métiers in Vilanova i la Geltrú).

Computing the indices over a time series should help to display trends and changes in dominance among fleets and their independence level over time. A practi-

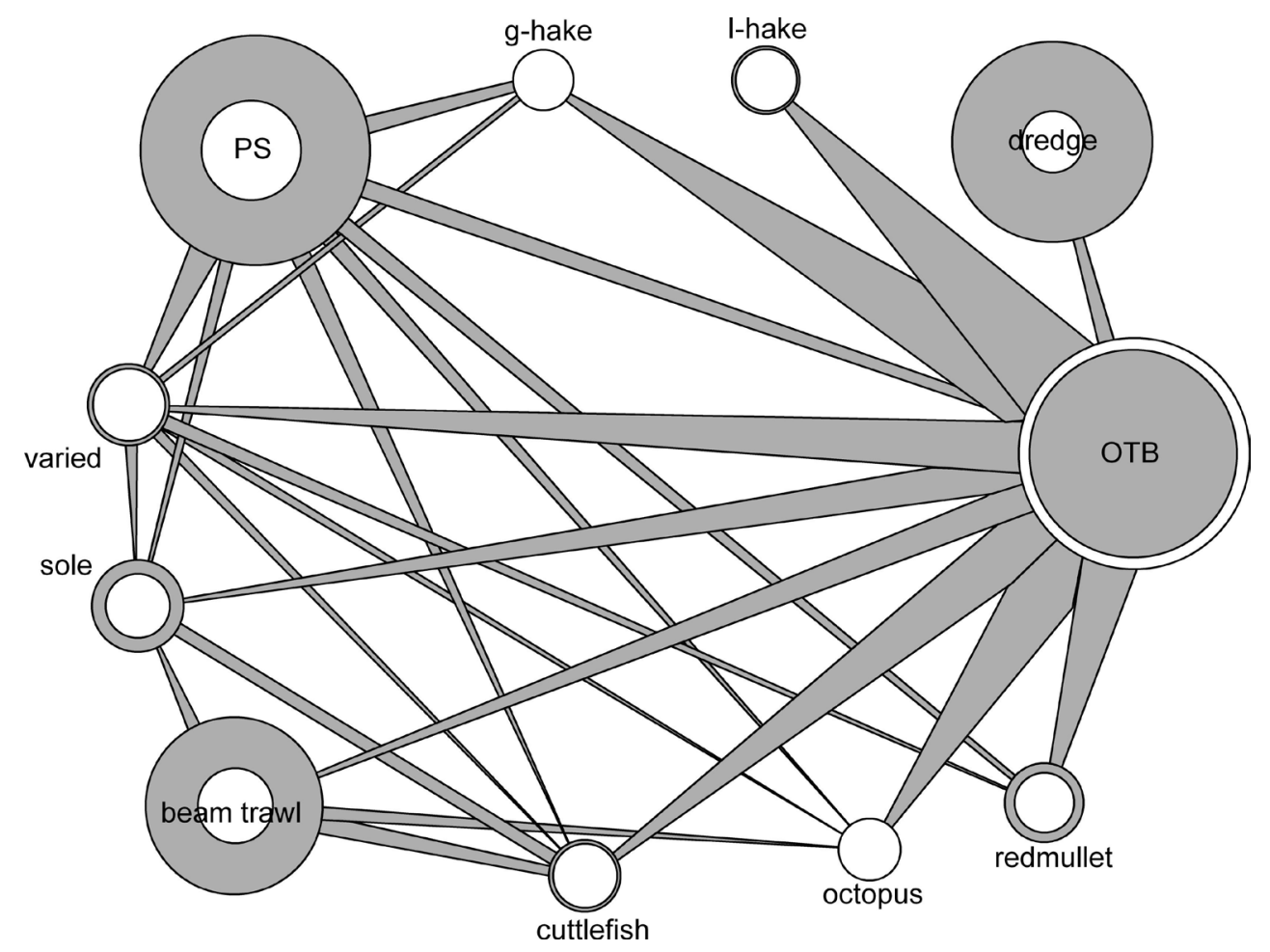

FIG. 4. - Sociogram of 11 fleets in Vilanova i la Geltrú. The white circle is proportional to $\mathrm{T}$ (dominance) the grey one to the main diagonal (independence). The arrows corresponding to values smaller than $5 \%$ of the interval of [S] have been eliminated for clarity. Of the 55 total pair relationships only 25 have been retained. 

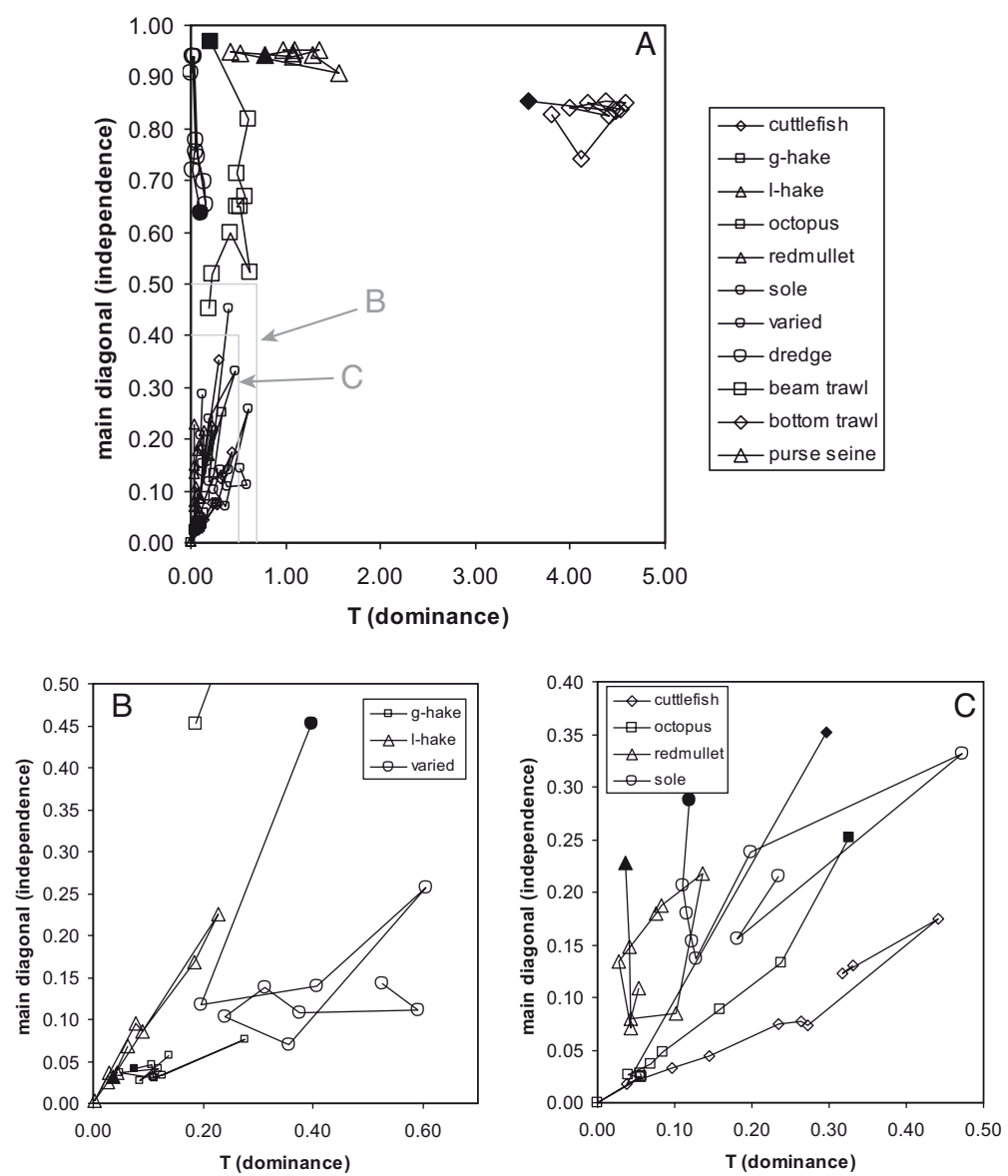

FIG. 5. - Independence vs dominance plot of 11F Catalonia, showing the annual trends. The first year of the series (2000) is indicated by a solid dot. In A the whole plot to note the positions of bottom trawl, purse seine, beam trawl and dredge is presented. The other seven fleets are presented in plots $\mathrm{B}$ and $\mathrm{C}$ to discriminate them.

cal use of these asymmetric indices is to assist fisheries managers in decision-making to optimize the allocation of fishing effort, i.e. to increase the independence of fleets and decrease the dominance, thus reducing a kind of competition that yields benefits in the short term and to the less selective fleets and also helping to minimize social conflict. For instance, Lleonart et al. (2003), under a bioeconomic perspective, show that reducing the effort allocated to bottom trawl would enhance the productivity of small-scale longliners, which compete with bottom trawl for European hake (Merluccius merluccius).

Although the purpose of this paper is limited to studying competition between gears in a strict technical interaction scenario, these asymmetric indices could also be useful for examining other aspects of fisheries, such as unwanted by-catch that is ultimately discarded, fisheries employment and efficiency in fuel consumption (Suuronen et al. 2012). In particular, the application of such indices to the study of economic competition could be useful and the object of possible future expansion. Indeed bottom trawl, the dominant gear, uses large amounts of fuel and its competitiveness and even economic sustainability is dependent on the fuel tax exemption.
In the NW Mediterranean the classification of fleets as industrial or artisanal (or small-scale) is not as clear as that in other parts of the world. Following the multivariate definition of "artisanal fishery" proposed by Coppola (2006) and Griffiths et al. (2007), not a single fleet can be identified as fully artisanal (or industrial) in this area of the Mediterranean. The equipment of these small-scale fleets is "modern" or "intermediate" (sensu Misund et al. 2002) and in some cases (some longliners or netters) the small-scale fleets are technically more advanced than the dominant industrial bottom trawl or purse seine fleets.

Different gears often target different sizes of a species. For example, trawl and longline fleets can compete for the same species but over different size ranges. In Mediterranean fisheries, a classic example is European hake: juvenile hake (10-30 cm TL) are mainly caught by trawlers, while large juveniles and adults (larger than $30 \mathrm{~cm}$ TL) are caught by longliners or gillnetters, raising the problem of technical interaction within the same species (Lleonart et al. 2003). In cases in which the commercial catch reports are disaggregated according to size (the commercial categories "small hake" and "large hake"), the different sizes could be taken as different species for competition 
analysis using the index developed here. However, our index is not dynamic and does not take into account delayed competition (i.e. the effect of present catches of juveniles on future abundance of spawning adults).

In another possible expansion, the use of these indices can be extended to assess the competition (dominance/independence continuum) of fleets from different countries or world regions or to assess the relationship between different seafood producing sectors (fisheries vs aquaculture) from readily available data such as the FAO fish production data sets.

\section{REFERENCES}

Aldebert Y., Recasens L. 1996. Comparison of methods for stock assessment of European hake Merluccius merluccius in the Gulf of Lions (Northwestern Mediterranean). Aquat. Living Resour. 9: $13-22$

Aldebert Y., Recasens L., Lleonart J. 1993. Analysis of gear interactions in a hake fishery: the case of the gulf of Lions (NW Mediterranean). Sci. Mar. 57: 201-217.

Coppola, S.R. 2006. Inventory of artisanal fishery communities in the Western and Central Mediterranean. Studies and Reviews. General Fisheries Commission for the Mediterranean. No. 77. Rome FAO, $82 \mathrm{pp}$.

Demestre M., Sbrana M., Alvarez F., Sánchez P. 1997. Analysis of the interaction of fishing gear in Mullus barbatus fisheries of the Western Mediterranean. J. Appl. Ichthyol. 13: 49-56.

Erzini K., Gonçalves J.M.S., Bentes L., Lino P.G., Ribeiro J., Stergiou K.I. 2003. Quantifying the roles of competing static gears: comparative selectivity of longlines and monofilament gill nets in a multi-species fishery of the Algarve (southern Portugal). Sci. Mar. 67(3): 341-352

Gallopín G.C. 1972. Trophic similarity between species in a food web. Am. Midl. Nat., 87(2): 336-345.

Griffiths R.C., Robles R., Coppola S.R., Camiñas J.A. 2007. Is there a future for artisanal fisheries in the Western Mediterranean? Rome FAO, Copemed, 106 pp.

Kuparinen A., Kuikka S., Merilä J. 2009. Estimating fisheriesinduced selection: traditional gear selectivity research meets fisheries-induced evolution. Evol. Appl. 2: 234-243.

Lewejohann L. 2005. Sociogram (Version 1.0). [Computer software]. http://www.phenotyping.com/sociogram/

Lleonart J., Maynou F., Recasens L., Franquesa R. 2003. A bioeconomic model for Mediterranean fisheries, the hake off Catalonia (western Mediterranean) as a case study. Sci. Mar. 67(Suppl. 1): $337-351$.

Maynou F., Recasens L., Lombarte A. 2011. Fishing tactics dynamics of a Mediterranean small-scale coastal fishery. Aquat. Living Resour. 24: 149-159.

Misund O.A., Kolding J., Fréon P. 2002. Fish capture devices in industrial and artisanal fisheries and their influence on management. In: Hart P.J.B., Reynolds J.D. (eds), Handbook of Fish Biology and Fisheries, vol. II, Blackwell Science, London, pp. 13-36.

Mouillot D., Stubbs W., Faure M., Dumay O., Tomasini J.A. Wilson J.B., Chi T.D. 2005. Niche overlap estimates based on quantitative functional traits: a new family of non-parametric indices. Mar. Biol. 145: 345-353.

Pelletier D., Ferraris J. 2000. A multivariate approach for defining fishing tactics from commercial catch and effort data. Can. J. Fish. Aquat. Sci. 57: 51-65.

Pledger S., Geange S.W. 2009. Niche overlap: A unified definition and analysis for data of different types. Research Report 200905 of the School of Mathematics, Statistics and Operations Research. Victoria University of Wellington, New Zealand.

Stergiou K.I., Petrakis G., Politou C.-Y. 1996. Small-scale fisheries in the South Euboikos Gulf (Greece): species composition and gear competition. Fish. Res. 26: 325-336

Suuronen P., Chopin F., Glass C., Løkkeborg S., Matsushita Y., Queirolo D., Rihan D. 2012. Low impact and fuel efficient fishing - looking beyond the horizon. Fish. Res. 119-120: 135-146.

Scient. ed.: B. Roel.

Received July 2, 2012. Accepted November 27, 2012.

Published online February 4, 2013. 
Appendix 1. - Official landing statistics in Catalonia. Total catches in the period (2000-2009), in kg, by species according to five main gears. OTB, otter bottom trawl; PG, passive gear; PS, purse seine; LLS, stet longline; LLD, drifting longline.

\begin{tabular}{|c|c|c|c|c|c|c|}
\hline & OTB & PG & PS & LLS & LLD & TOTAL \\
\hline Sardina pilchardus & 1301717 & 546540 & 94823605 & 96162 & 4170 & 96772194 \\
\hline Engraulis encrasicolus & 1510504 & 362664 & 38778963 & 67195 & 319 & 40719645 \\
\hline Merluccius merluccius & 14743399 & 3323898 & 16601 & 1905810 & 247818 & 20237526 \\
\hline Micromesistius poutassou & 15490461 & 261094 & 5387 & 23030 & 1359 & 15781331 \\
\hline Scomber scombrus & 6806130 & 479864 & 6709665 & 44348 & 898 & 14040905 \\
\hline Trachurus trachurus & 8276997 & 352119 & 4200165 & 83926 & 806 & 12914013 \\
\hline Eledone cirrhosa & 9720859 & 139163 & 4688 & 13843 & 16 & 9878569 \\
\hline Osteichthyes & 5703179 & 849431 & 666274 & 140577 & 53741 & 7413202 \\
\hline Sardinella aurita & 21192 & 53740 & 7128198 & 368 & 0 & 7203498 \\
\hline Octopus vulgaris & 3288375 & 3694013 & 4856 & 162187 & 479 & 7149910 \\
\hline Squilla mantis & 4182022 & 452079 & 12 & 8035 & 0 & 4642148 \\
\hline Trachurus mediterraneus & 1200527 & 41956 & 2785326 & 11953 & 872 & 4040634 \\
\hline Lophius piscatorius & 3859639 & 158719 & 1151 & 14628 & 467 & 4034604 \\
\hline Trisopterus minutus & 3940599 & 43473 & 1264 & 5219 & 600 & 3991155 \\
\hline Aristeus antennatus & 3837619 & 59798 & 2373 & 1314 & 0 & 3901104 \\
\hline Scomber japonicus & 66598 & 129875 & 3527483 & 36258 & 3782 & 3763996 \\
\hline Nephrops norvegicus & 3193394 & 25888 & 1344 & 533 & 0 & 3221159 \\
\hline Sparus aurata & 1406809 & 771464 & 815290 & 34080 & 34 & 3027677 \\
\hline Pagellus acarne & 2095930 & 252016 & 437616 & 57144 & 5510 & 2848216 \\
\hline Mullus surmuletus & 2461347 & 333707 & 1370 & 12733 & 587 & 2809744 \\
\hline Conger conger & 1745224 & 620452 & 11055 & 388879 & 28757 & 2794367 \\
\hline Citharus linguatula & 2548220 & 128464 & 438 & 16126 & 6 & 2693254 \\
\hline Mullus barbatus & 2516169 & 110500 & 1580 & 4280 & 9 & 2632538 \\
\hline Phycis blennoides & 2270395 & 152061 & 1949 & 91123 & 5024 & 2520552 \\
\hline Gymnammodytes cicerelus & 55575 & 2317108 & 13097 & 124402 & 0 & 2510182 \\
\hline Sarda sarda & 33154 & 870708 & 1316618 & 96180 & 106971 & 2423631 \\
\hline Loligo vulgaris & 2186054 & 115277 & 115754 & 2611 & 1 & 2419697 \\
\hline Pagellus erythrinus & 1564126 & 613544 & 98660 & 76720 & 1366 & 2354416 \\
\hline Sepia officinalis & 1058942 & 1005465 & 5232 & 55614 & 89 & 2125342 \\
\hline Liocarcinus depurator & 1724093 & 7955 & 164 & 1599 & 0 & 1733811 \\
\hline Boops boops & 678192 & 29385 & 946797 & 9784 & 118 & 1664276 \\
\hline Cepola rubescens & 1600695 & 25111 & 932 & 90 & 11 & 1626839 \\
\hline Thunnus thynnus & 18933 & 233546 & 21828 & 107341 & 1084901 & 1466549 \\
\hline Bolinus brandaris & 340786 & 1008489 & 379 & 85684 & 15 & 1435353 \\
\hline Gobius niger & 1319409 & 51662 & 30554 & 6036 & 295 & 1407956 \\
\hline Lepidopus caudatus & 498433 & 354604 & 24043 & 341488 & 176741 & 1395309 \\
\hline Xiphias gladius & 45465 & 381329 & 41669 & 158449 & 756285 & 1383197 \\
\hline Dicentrarchus labrax & 686695 & 493493 & 37927 & 23041 & 1180 & 1242336 \\
\hline Solea vulgaris & 264785 & 908941 & 25481 & 26026 & 8 & 1225241 \\
\hline Chelidonichthys lucerna & 784297 & 210398 & 590 & 137166 & 22517 & 1154968 \\
\hline Illex coindetii & 1070468 & 4875 & 4924 & 822 & 2 & 1081091 \\
\hline Lophius budegassa & 916564 & 33627 & 552 & 3176 & 135 & 954054 \\
\hline Brachyura & 911997 & 6257 & 26 & 176 & 0 & 918456 \\
\hline Seriola dumerili & 293459 & 231391 & 376418 & 3082 & 174 & 904524 \\
\hline Pomatomus saltator & 185023 & 374441 & 263186 & 59607 & 1435 & 883692 \\
\hline Trachurus picturatus & 179506 & 9356 & 681937 & 886 & 2035 & 873720 \\
\hline Mugil cephalus & 535172 & 169045 & 141895 & 10861 & 6 & 856979 \\
\hline Lithognathus mormyrus & 198712 & 325907 & 312659 & 7066 & 9 & 844353 \\
\hline Mullus sp. & 728593 & 56063 & 662 & 102 & 0 & 785420 \\
\hline Todarodes sagittatus & 697725 & 24381 & 3289 & 1473 & 136 & 727004 \\
\hline Nassarius mutabilis & 81 & 715376 & 4 & 10011 & 0 & 725472 \\
\hline Diplodus sargus & 214408 & 288744 & 168810 & 33050 & 953 & 705965 \\
\hline Liza ramada & 32016 & 55560 & 582752 & 774 & 0 & 671102 \\
\hline Penaeus kerathurus & 326967 & 329617 & 791 & 10294 & 0 & 667669 \\
\hline Trachinus draco & 584635 & 69360 & 944 & 9549 & 140 & 664628 \\
\hline Sphyraena sphyraena & 350463 & 43463 & 239234 & 356 & 12 & 633528 \\
\hline Donax trunculus & 8 & 628516 & 673 & 1145 & 0 & 630342 \\
\hline Mugilidae & 221811 & 99491 & 248276 & 1216 & 0 & 570794 \\
\hline Auxis rochei & 9083 & 110867 & 402772 & 11165 & 2225 & 536112 \\
\hline Trisopterus luscus & 498529 & 16218 & 87 & 9288 & 10 & 524132 \\
\hline Parapenaeus longirostris & 465990 & 21674 & 2410 & 25 & 0 & 490099 \\
\hline Sarpa salpa & 13731 & 138979 & 311586 & 925 & 14 & 465235 \\
\hline Helicolenus dactylopterus & 236105 & 109619 & 246 & 101278 & 8538 & 455786 \\
\hline Cephalopoda & 383042 & 48962 & 26 & 5 & 0 & 432035 \\
\hline Trigla lyra & 400415 & 12988 & 104 & 11490 & 250 & 425247 \\
\hline Raja asterias & 213561 & 193630 & 355 & 9451 & 871 & 417868 \\
\hline Lepidorhombus boscii & 401203 & 4143 & 132 & 7 & 0 & 405485 \\
\hline Murex sp. & 53536 & 301187 & 5 & 43565 & 54 & 398347 \\
\hline Diplodus annularis & 212411 & 70612 & 100775 & 2146 & 0 & 385944 \\
\hline Thunnus alalunga & 2528 & 24037 & 37246 & 3249 & 305486 & 372546 \\
\hline Chamelea gallina & 226 & 355995 & 29 & 2729 & 0 & 358979 \\
\hline
\end{tabular}


APPENDIX 1 (cont.). - Official landing statistics in Catalonia. Total catches in the period (2000-2009), in kg, by species according to five main gears. OTB, otter bottom trawl; PG, passive gear; PS, purse seine; LLS, stet longline; LLD, drifting longline.

\begin{tabular}{|c|c|c|c|c|c|c|}
\hline & OTB & PG & PS & LLS & LLD & TOTAL \\
\hline Eutrigla gurnardus & 350489 & 1841 & 51 & 1819 & 13 & 354213 \\
\hline Uranoscopus scaber & 214386 & 100636 & 352 & 12265 & 0 & 327639 \\
\hline Oblada melanura & 2995 & 19246 & 302504 & 2591 & 0 & 327336 \\
\hline Diplodus vulgaris & 225392 & 54472 & 34262 & 3182 & 67 & 317375 \\
\hline Coryphaena hippurus & 24470 & 226700 & 16833 & 17435 & 30944 & 316382 \\
\hline Lichia amia & 120657 & 159750 & 31981 & 3244 & 206 & 315838 \\
\hline Octopodidae & 230027 & 71986 & 57 & 254 & 10 & 302334 \\
\hline Lophius sp. & 296795 & 2604 & 4 & 2668 & 51 & 302122 \\
\hline Gobiidae & 270489 & 8280 & 12509 & 615 & 81 & 291974 \\
\hline Zeus faber & 238807 & 25536 & 404 & 6940 & 564 & 272251 \\
\hline Brama brama & 1832 & 58005 & 383 & 23237 & 167238 & 250695 \\
\hline Pagellus bogaraveo & 74793 & 107075 & 662 & 64021 & 2333 & 248884 \\
\hline Sepia elegans & 238048 & 683 & 9 & 1 & 0 & 238741 \\
\hline Argentina sphyraena & 237404 & 964 & 20 & 4 & 0 & 238392 \\
\hline Liza aurata & 3764 & 5349 & 202074 & 359 & 23 & 211569 \\
\hline Trachinus sp. & 122365 & 62785 & 58 & 2271 & 100 & 187579 \\
\hline Scyliorhinus canicula & 169816 & 10344 & 123 & 4682 & 1475 & 186440 \\
\hline Phycis phycis & 132880 & 35752 & 10 & 13207 & 3899 & 185748 \\
\hline Pagrus pagrus & 54685 & 109532 & 4553 & 14960 & 1643 & 185373 \\
\hline Eledone moschata & 177309 & 491 & 3 & 90 & 0 & 177893 \\
\hline Spicara smaris & 47398 & 22328 & 98923 & 17 & 20 & 168686 \\
\hline Hexaplex trunculus & 2965 & 147507 & 44 & 7543 & 0 & 158059 \\
\hline Dentex dentex & 53593 & 82758 & 11134 & 6837 & 196 & 154518 \\
\hline Arnoglossus thori & 149904 & 752 & 171 & 42 & 0 & 150869 \\
\hline Raja sp. & 71545 & 56605 & 27 & 10728 & 1122 & 140027 \\
\hline Trigla sp. & 119648 & 12730 & 0 & 16 & 0 & 132394 \\
\hline Plesionika heterocarpus & 129377 & 3379 & 247 & 0 & 0 & 133003 \\
\hline Euthynnus alletteratus & 193 & 84623 & 37796 & 206 & 4215 & 127033 \\
\hline Scophthalmus rhombus & 41470 & 77408 & 117 & 4683 & 45 & 123723 \\
\hline Acanthocardia tuberculata & 28 & 121992 & 5 & 275 & 0 & 122300 \\
\hline Triglidae & 117150 & 3139 & 0 & 1326 & 7 & 121622 \\
\hline Galeus melastomus & 95977 & 10321 & 0 & 9736 & 3934 & 119968 \\
\hline Scorpaena scrofa & 23385 & 83096 & 315 & 10308 & 398 & 117502 \\
\hline Crustacea & 110214 & 1812 & 28 & 73 & 0 & 112127 \\
\hline Munida sp. & 102712 & 631 & 37 & 0 & 0 & 103380 \\
\hline Phycis sp. & 82128 & 10723 & 13 & 2205 & 1211 & 96280 \\
\hline Serranus cabrilla & 63815 & 23181 & 379 & 6284 & 53 & 93712 \\
\hline Lepidotrigla cavillone & 80070 & 684 & 0 & 20 & 0 & 80774 \\
\hline Scorpaena sp. & 21049 & 41032 & 724 & 14976 & 85 & 77866 \\
\hline Plesionika edwardsii & 71665 & 1416 & 18 & 0 & 0 & 73099 \\
\hline Octopus macropus & 70927 & 58 & 6 & 63 & 0 & 71054 \\
\hline Elasmobranchii & 33572 & 13966 & 5529 & 6849 & 6654 & 66570 \\
\hline Callista chione & 1002 & 61420 & 772 & 1795 & 0 & 64989 \\
\hline Sepiidae, Sepiolidae & 63629 & 1148 & 14 & 0 & 17 & 64808 \\
\hline Palinurus elephas & 14505 & 44781 & 27 & 2677 & 72 & 62062 \\
\hline Paromola cuvieri & 53515 & 2925 & 94 & 29 & 13 & 56576 \\
\hline Spondyliosoma cantharus & 8619 & 9091 & 32869 & 819 & 21 & 51419 \\
\hline Crystallogobius linearis & 56 & 50800 & 0 & 0 & 0 & 50856 \\
\hline Scorpaena porcus & 7734 & 40809 & 34 & 1643 & 0 & 50220 \\
\hline Lepidorhombus whiffiagonis & 45651 & 771 & 147 & 0 & 0 & 46569 \\
\hline Belone belone & 1730 & 1922 & 38775 & 369 & 3 & 42799 \\
\hline Sciaena umbra & 5990 & 29862 & 1474 & 1567 & 7 & 38900 \\
\hline Raja clavata & 22887 & 8736 & 14 & 6363 & 863 & 38863 \\
\hline Scorpaena notata & 6619 & 29141 & 906 & 1314 & 93 & 38073 \\
\hline Stichopus regalis & 30001 & 436 & 6140 & 57 & 0 & 36634 \\
\hline Psetta maxima & 16151 & 19432 & 166 & 365 & 33 & 36147 \\
\hline Bothus podas & 5491 & 29350 & 37 & 368 & 0 & 35246 \\
\hline Umbrina ronchus & 16747 & 17910 & 1 & 39 & 41 & 34738 \\
\hline Serranus sp. & 16556 & 16242 & 257 & 724 & 19 & 33798 \\
\hline Etmopterus spinax & 30769 & 391 & 65 & 30 & 13 & 31268 \\
\hline Geryon longipes & 26380 & 2820 & 10 & 0 & 0 & 29210 \\
\hline Squalus acanthias & 16585 & 8747 & 2613 & 669 & 42 & 28656 \\
\hline Polipryon americanus & 3162 & 5646 & 7357 & 6217 & 3680 & 26062 \\
\hline Littorina littorea & 1 & 21069 & 0 & 0 & 0 & 21070 \\
\hline Paracentrotus lividus & 3598 & 11105 & 358 & 5369 & 0 & 20430 \\
\hline Diplodus puntazzo & 3693 & 3108 & 13252 & 368 & 0 & 20421 \\
\hline Necora puber & 19052 & 1223 & 1 & 81 & 0 & 20357 \\
\hline Anguilla anguilla & 16797 & 3087 & 30 & 23 & 99 & 20036 \\
\hline Myliobatis aquila & 8959 & 8680 & 90 & 842 & 0 & 18571 \\
\hline Dasyatis pastinaca & 11460 & 6974 & 0 & 0 & 0 & 18434 \\
\hline Carcinus aestuarii & 243 & 17393 & 0 & 0 & 0 & 17636 \\
\hline
\end{tabular}


Appendix 1 (cont.). - Official landing statistics in Catalonia. Total catches in the period (2000-2009), in kg, by species according to five main gears. OTB, otter bottom trawl; PG, passive gear; PS, purse seine; LLS, stet longline; LLD, drifting longline.

\begin{tabular}{|c|c|c|c|c|c|c|}
\hline & OTB & PG & PS & LLS & LLD & TOTAL \\
\hline Aphia minuta & 67 & 16990 & 0 & 0 & 0 & 17057 \\
\hline Molva dipterygia & 14065 & 258 & 8 & 1357 & 58 & 15746 \\
\hline Epinephelus marginatus & 3994 & 9397 & 38 & 1341 & 172 & 14942 \\
\hline Homarus gammarus & 2737 & 8700 & 12 & 353 & 2 & 11804 \\
\hline Umbrina cirrosa & 2164 & 9506 & 39 & 88 & 3 & 11800 \\
\hline Tapes decussatus & 771 & 9869 & 707 & 144 & 0 & 11491 \\
\hline Pecten jacobaeus & 1553 & 7106 & 0 & 1943 & 0 & 10602 \\
\hline Aristeidae & 8367 & 303 & 931 & 0 & 0 & 9601 \\
\hline Thais haemastoma & 4368 & 3393 & 0 & 137 & 0 & 7898 \\
\hline Deltentosteus quadrimaculatus & 24 & 7634 & 14 & 0 & 0 & 7672 \\
\hline Calappa granulata & 4541 & 2449 & 0 & 490 & 0 & 7480 \\
\hline Labridae & 118 & 7087 & 6 & 193 & 0 & 7404 \\
\hline Veneridae & 51 & 6772 & 100 & 328 & 0 & 7251 \\
\hline Circomphalus casinus & 5233 & 1458 & 0 & 0 & 0 & 6691 \\
\hline Torpedo marmorata & 1265 & 4289 & 0 & 0 & 0 & 5554 \\
\hline Diplodus cervinus & 1755 & 2047 & 1588 & 72 & 0 & 5462 \\
\hline Condrichthyes & 4665 & 374 & 26 & 4 & 293 & 5362 \\
\hline Cerastoderma glaucum & 0 & 4940 & 0 & 0 & 0 & 4940 \\
\hline Naticarius cruentatus & 1526 & 2909 & 0 & 20 & 0 & 4455 \\
\hline Coris julis & 48 & 3124 & 708 & 188 & 0 & 4068 \\
\hline Muraena helena & 231 & 3203 & 12 & 595 & 5 & 4022 \\
\hline Carcinus maenas & 8 & 3926 & 0 & 0 & 0 & 3934 \\
\hline Mora moro & 3494 & 7 & 0 & 5 & 2 & 3508 \\
\hline Galeorhinus galeus & 1658 & 810 & 833 & 135 & 18 & 3454 \\
\hline Lamna nasus & 290 & 283 & 16 & 292 & 552 & 1433 \\
\hline Invertebrata & 825 & 439 & 0 & 0 & 61 & 1325 \\
\hline Glycymeris insubrica & 0 & 1041 & 0 & 0 & 84 & 1125 \\
\hline Mactra corallina & 31 & 1083 & 0 & 0 & 0 & 1114 \\
\hline Serranus hepatus & 328 & 648 & 0 & 0 & 0 & 976 \\
\hline Holothurioidea & 930 & 0 & 0 & 0 & 0 & 930 \\
\hline Dactylopterus volitans & 186 & 641 & 0 & 0 & 0 & 827 \\
\hline Maja squinado & 698 & 5 & 0 & 0 & 0 & 703 \\
\hline Spicara sp. & 398 & 231 & 0 & 0 & 0 & 629 \\
\hline Tapes philippinarum & 0 & 458 & 0 & 0 & 0 & 458 \\
\hline Oxynotus centrina & 433 & 0 & 0 & 0 & 0 & 433 \\
\hline Glycymeris pilosa & 7 & 407 & 0 & 0 & 0 & 414 \\
\hline Bivalvia & 26 & 243 & 0 & 0 & 0 & 269 \\
\hline Raja miraletus & 126 & 134 & 0 & 5 & 0 & 265 \\
\hline Cetorhinus maximus & 251 & 0 & 0 & 0 & 0 & 251 \\
\hline Scyllarus arctus & 50 & 186 & 0 & 7 & 0 & 243 \\
\hline Ostrea edulis & 30 & 181 & 0 & 0 & 0 & 211 \\
\hline Mollusca & 141 & 42 & 0 & 0 & 0 & 183 \\
\hline Somniosus rostratus & 0 & 143 & 0 & 0 & 39 & 182 \\
\hline Capros aper & 141 & 0 & 0 & 0 & 0 & 141 \\
\hline Balistes carolinensis & 33 & 102 & 0 & 0 & 0 & 135 \\
\hline Scyllarides latus & 38 & 68 & 0 & 7 & 0 & 113 \\
\hline Mola mola & 22 & 31 & 0 & 0 & 0 & 53 \\
\hline Mytilus edulis & 40 & 7 & 0 & 0 & 0 & 47 \\
\hline Microcosmus vulgaris & 29 & 16 & 0 & 0 & 0 & 45 \\
\hline Chimaera monstrosa & 32 & 6 & 0 & 0 & 0 & 38 \\
\hline Acanthocardia echinata & 35 & 0 & 0 & 0 & 0 & 35 \\
\hline Ensis siliqua & 0 & 17 & 0 & 0 & 0 & 17 \\
\hline Aristaeomorpha foliacea & 13 & 0 & 0 & 0 & 0 & 13 \\
\hline Atrina fragilis & 12 & 0 & 0 & 0 & 0 & 12 \\
\hline Torpedo nobiliana & 0 & 11 & 0 & 0 & 0 & 11 \\
\hline Crassostrea gigas & 0 & 4 & 0 & 0 & 0 & 4 \\
\hline Total & 130586525 & 29284543 & 167362065 & 5116415 & 3061129 & 335410677 \\
\hline
\end{tabular}


ApPendix 2. - Official landings at Vilanova i la Geltrú. Annual average values (2000-2009), in kg, by species, according to 11 métiers.

\begin{tabular}{|c|c|c|c|c|c|c|c|c|c|c|c|c|}
\hline & cuttlefish & g-hake & 1-hake & octopus & redmullet & sole & varied & dredge & beam & bottom & purse & Total \\
\hline Sardina pilchardus & 0 & 0 & 0 & 0 & 0 & 0 & 0 & 0 & 0 & 4048 & 976524 & 980571 \\
\hline Engraulis encrasicolus & 0 & 0 & 0 & 0 & 0 & 0 & 0 & 0 & 1 & 3558 & 273487 & 277045 \\
\hline Trachurus mediterraneus & 35 & 314 & 165 & 15 & 99 & 5 & 885 & 6 & 3 & 47522 & 88995 & 138045 \\
\hline Merluccius merluccius & 64 & 4403 & 8940 & 43 & 2 & 97 & 1105 & 2 & 26 & 101082 & 5 & 115767 \\
\hline Micromesistius poutassou & 0 & 0 & 0 & 0 & 0 & 0 & 0 & 0 & 0 & 110878 & 95 & 110973 \\
\hline Sardinella aurita & 0 & 0 & 0 & 0 & 0 & 0 & 0 & 0 & 0 & 61 & 70208 & 70269 \\
\hline Scomber scombrus & 9 & 855 & 97 & 1 & 1 & 0 & 207 & 1 & 1 & 18465 & 38702 & 58339 \\
\hline Eledone cirrhosa & 0 & 0 & 0 & 0 & 0 & 0 & 0 & 0 & 124 & 53733 & 0 & 53857 \\
\hline Osteichthyes & 123 & 571 & 216 & 64 & 117 & 59 & 1406 & 21 & 252 & 37799 & 7242 & 47871 \\
\hline Octopus vulgaris & 415 & 97 & 10 & 6193 & 287 & 277 & 796 & 589 & 1083 & 30759 & 219 & 40724 \\
\hline Pagellus acarne & 84 & 539 & 68 & 44 & 52 & 11 & 1544 & 1 & 11 & 31297 & 6950 & 40602 \\
\hline Scomber japonicus & 0 & 24 & 1 & 1 & 2 & 0 & 43 & 0 & 0 & 440 & 39189 & 39699 \\
\hline Mullus barbatus & 9 & 12 & 2 & 12 & 28 & 9 & 98 & 5 & 4 & 37473 & 27 & 37677 \\
\hline Sparus aurata & 74 & 73 & 25 & 35 & 5 & 9 & 1051 & 9 & 2 & 2300 & 28433 & 32015 \\
\hline Liza ramada & 67 & 55 & 7 & 35 & 6 & 25 & 571 & 1 & 0 & 1118 & 22636 & 24521 \\
\hline Lophius piscatorius & 35 & 145 & 35 & 4 & 6 & 20 & 187 & 1 & 84 & 23444 & 15 & 23977 \\
\hline Aristeus antennatus & 0 & 0 & 0 & 0 & 0 & 0 & 0 & 0 & 0 & 22817 & 0 & 22817 \\
\hline Seriola dumerili & 87 & 285 & 33 & 120 & 22 & 26 & 2878 & 6 & 2 & 2678 & 15998 & 22137 \\
\hline Lithognathus mormyrus & 327 & 193 & 23 & 119 & 93 & 330 & 2274 & 451 & 36 & 659 & 16903 & 21409 \\
\hline Sepia officinalis & 1670 & 72 & 21 & 191 & 102 & 316 & 339 & 1267 & 1518 & 14613 & 48 & 20156 \\
\hline Loligo vulgaris & 0 & 0 & 0 & 0 & 0 & 0 & 0 & 0 & 1 & 16110 & 3780 & 19891 \\
\hline Trachurus trachurus & 8 & 18 & 3 & 1 & 6 & 0 & 38 & 2 & 0 & 6284 & 12571 & 18934 \\
\hline Phycis blennoides & 3 & 83 & 34 & 0 & 1 & 1 & 46 & 0 & 2 & 18116 & 0 & 18287 \\
\hline Citharus linguatula & 8 & 126 & 46 & 7 & 0 & 5 & 56 & 0 & 463 & 16189 & 0 & 16900 \\
\hline Sarda sarda & 47 & 453 & 31 & 38 & 5 & 2 & 3110 & 0 & 2 & 138 & 12046 & 15873 \\
\hline Pagellus erythrinus & 49 & 460 & 70 & 22 & 53 & 8 & 937 & 0 & 20 & 9902 & 3121 & 14641 \\
\hline Nephrops norvegicus & 0 & 0 & 0 & 0 & 0 & 0 & 0 & 0 & 0 & 14514 & 0 & 14514 \\
\hline Sarpa salpa & 7 & 11 & 3 & 8 & 4 & 3 & 131 & 11 & 1 & 64 & 12985 & 13228 \\
\hline Bolinus brandaris & 858 & 12 & 9 & 140 & 21 & 173 & 160 & 14 & 10990 & 327 & 0 & 12704 \\
\hline Trisopterus minutus & 1 & 37 & 30 & 1 & 0 & 9 & 11 & 0 & 4 & 11538 & 0 & 11632 \\
\hline Pomatomus saltator & 3 & 8 & 2 & 16 & 1 & 3 & 210 & 2 & 2 & 60 & 11142 & 11451 \\
\hline Trachinus draco & 43 & 59 & 11 & 26 & 12 & 101 & 186 & 1 & 95 & 9972 & 3 & 10509 \\
\hline Mullus surmuletus & 55 & 77 & 12 & 16 & 1576 & 2 & 286 & 13 & 3 & 8242 & 19 & 10304 \\
\hline Diplodus sargus & 64 & 103 & 14 & 60 & 13 & 14 & 899 & 15 & 2 & 1050 & 8015 & 10249 \\
\hline Liocarcinus depurator & 0 & 0 & 0 & 0 & 0 & 0 & 0 & 0 & 14 & 9234 & 7 & 9255 \\
\hline Chelidonichthys lucerna & 195 & 297 & 181 & 49 & 8 & 69 & 326 & 1 & 50 & 7925 & 2 & 9104 \\
\hline Boops boops & 0 & 0 & 0 & 0 & 0 & 0 & 0 & 0 & 0 & 5444 & 3319 & 8763 \\
\hline Sphyraena sphyraena & 1 & 4 & 0 & 13 & 163 & 0 & 73 & 5 & 0 & 1297 & 6897 & 8454 \\
\hline Oblada melanura & 0 & 0 & 0 & 0 & 0 & 0 & 0 & 0 & 0 & 0 & 7603 & 7603 \\
\hline Conger conger & 6 & 16 & 3 & 22 & 6 & 2 & 195 & 23 & 14 & 7269 & 26 & 7582 \\
\hline Eledone moschata & 0 & 0 & 0 & 0 & 0 & 0 & 0 & 0 & 7059 & 257 & 0 & 7316 \\
\hline Solea vulgaris & 895 & 142 & 62 & 288 & 70 & 2343 & 753 & 16 & 1180 & 598 & 12 & 6359 \\
\hline Dicentrarchus labrax & 83 & 40 & 19 & 106 & 7 & 22 & 615 & 43 & 28 & 4045 & 1222 & 6230 \\
\hline Donax trunculus & 0 & 0 & 0 & 0 & 0 & 0 & 0 & 5936 & 0 & 0 & 0 & 5936 \\
\hline Cepola rubescens & 0 & 0 & 0 & 0 & 0 & 0 & 0 & 0 & 0 & 5846 & 0 & 5846 \\
\hline Mugilidae & 0 & 0 & 0 & 0 & 0 & 0 & 0 & 0 & 0 & 63 & 4649 & 4712 \\
\hline Brachyura & 0 & 0 & 0 & 0 & 0 & 0 & 0 & 0 & 1 & 4238 & 2 & 4242 \\
\hline Diplodus annularis & 18 & 67 & 10 & 11 & 24 & 2 & 339 & 3 & 1 & 2443 & 1182 & 4098 \\
\hline Pagrus pagrus & 24 & 52 & 15 & 48 & 124 & 13 & 767 & 0 & 1 & 2895 & 117 & 4056 \\
\hline Lepidorhombus boscii & 0 & 0 & 0 & 0 & 0 & 0 & 0 & 0 & 0 & 3804 & 0 & 3804 \\
\hline Uranoscopus scaber & 17 & 26 & 12 & 2 & 19 & 8 & 51 & 1 & 232 & 2794 & 1 & 3161 \\
\hline Parapenaeus longirostris & 0 & 0 & 0 & 0 & 0 & 0 & 0 & 0 & 0 & 3081 & 0 & 3081 \\
\hline Diplodus vulgaris & 5 & 11 & 2 & 3 & 10 & 2 & 126 & 0 & 2 & 1495 & 1088 & 2745 \\
\hline Raja asterias & 147 & 104 & 9 & 29 & 20 & 39 & 145 & 1 & 489 & 1425 & 0 & 2407 \\
\hline Trisopterus luscus & 0 & 0 & 0 & 0 & 0 & 0 & 0 & 0 & 0 & 2125 & 0 & 2125 \\
\hline Squilla mantis & 27 & 3 & 1 & 13 & 0 & 32 & 13 & 0 & 316 & 1620 & 0 & 2025 \\
\hline Illex coindetii & 0 & 0 & 0 & 0 & 0 & 0 & 0 & 0 & 0 & 1564 & 139 & 1702 \\
\hline Scorpaena notata & 21 & 45 & 9 & 13 & 536 & 30 & 302 & 3 & 8 & 500 & 88 & 1555 \\
\hline Scophthalmus rhombus & 269 & 21 & 4 & 87 & 39 & 89 & 175 & 4 & 334 & 406 & 4 & 1431 \\
\hline Galeus melastomus & 0 & 0 & 0 & 0 & 0 & 0 & 0 & 0 & 0 & 1370 & 0 & 1370 \\
\hline Scyliorhinus canicula & 0 & 0 & 0 & 0 & 0 & 0 & 0 & 0 & 0 & 1289 & 0 & 1289 \\
\hline Helicolenus dactylopterus & 0 & 46 & 26 & 0 & 0 & 0 & 16 & 0 & 1 & 1178 & 0 & 1267 \\
\hline Penaeus kerathurus & 33 & 5 & 2 & 2 & 0 & 16 & 38 & 0 & 813 & 240 & 11 & 1159 \\
\hline Dentex dentex & 6 & 48 & 16 & 4 & 15 & 2 & 231 & 0 & 1 & 383 & 420 & 1126 \\
\hline Nassarius mutabilis & 39 & 0 & 0 & 1 & 0 & 0 & 798 & 287 & 0 & 0 & 0 & 1126 \\
\hline Plesionika heterocarpus & 0 & 0 & 0 & 0 & 0 & 0 & 0 & 0 & 0 & 1094 & 0 & 1094 \\
\hline Hexaplex trunculus & 0 & 0 & 0 & 0 & 0 & 0 & 0 & 2 & 1010 & 43 & 0 & 1055 \\
\hline Xiphias gladius & 1 & 37 & 58 & 0 & 0 & 0 & 19 & 0 & 0 & 422 & 435 & 973 \\
\hline Dactylopterus volitans & 0 & 0 & 0 & 0 & 0 & 0 & 0 & 942 & 23 & 0 & 0 & 964 \\
\hline Lophius sp. & 0 & 0 & 0 & 0 & 0 & 0 & 0 & 0 & 1 & 902 & 0 & 902 \\
\hline Spicara smaris & 0 & 0 & 0 & 0 & 0 & 0 & 0 & 0 & 0 & 224 & 636 & 860 \\
\hline
\end{tabular}


APPENDiX 2 (cont.). - Official landings at Vilanova i la Geltrú. Annual average values (2000-2009), in kg, by species, according to 11 métiers.

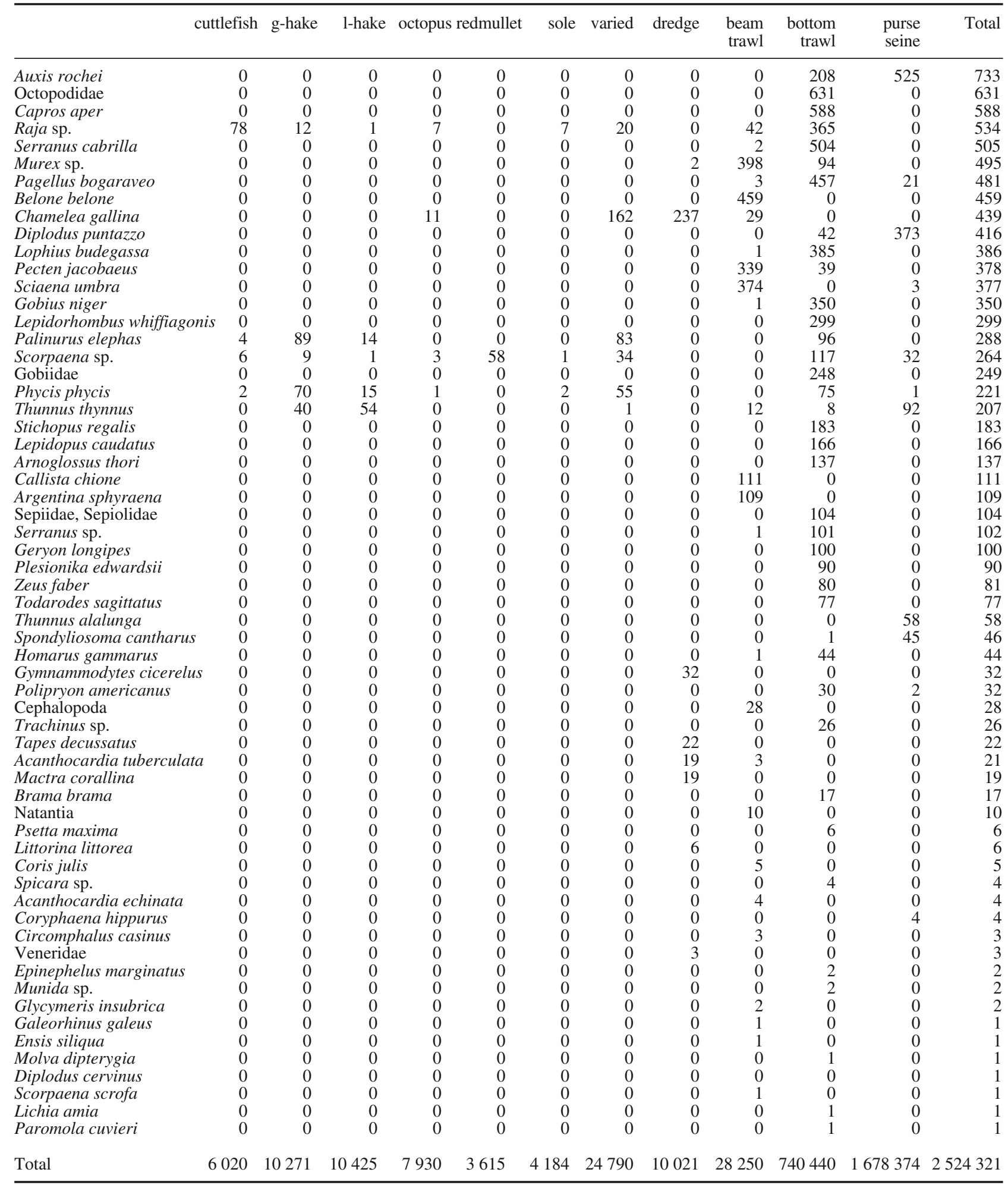

